\title{
MEKANISME ADAPTASI AKAR DAN SERAPAN FOSFOR SPESIFIK TIGA GENOTIPE KEDELAI SEBAGAI RESPON TERHADAP KEKAHATAN FOSFOR PADA TANAH MASAM
}

\section{SPECIFIC PHOSPHORUS ABSORPTION AND ROOT ADAPTATION MECHANISMS OF THREE SOYBEAN GENOTYPES AS RESPONSES TO PHOSPHORUS DEFICIENCY IN ACID SOIL}

\author{
Parpen Siregar \\ Dinas Pertanian dan Peternakan, Kabupaten Bengkulu Utara
}

\begin{abstract}
ABSTRAK
Tujuan penelitian adalah mempelajari (1) mekanisme adaptasi genotipe baru kedelai mendapatkan $\mathrm{P}$ dari tanah mineral masam kahat $\mathrm{P}$ melalui translokasi karbon ke akar dan serapan P spesifik, dan (2) respon genotipe baru kedelai terhadap pemupukan $\mathrm{P}$ dosis tinggi. Percobaan disusun dengan Rancangan Acak Lengkap (RAL) faktorial. Faktor pertama ialah genotipe kedelai (Slamet, 19BE, dan 25EC). Faktor kedua ialah pemupukan P (0 dan $400 \mathrm{mg}$ $\mathrm{P} \mathrm{kg}^{-1}$ ) dalam bentuk $\mathrm{KH}_{2} \mathrm{PO}_{4}$. Semua kombinasi perlakuan diulang empat kali. Tanaman kedelai dibudidayakan di rumah kaca menggunakan sistem pot ganda (double pot). Data yang diperoleh diuji secara statistika dengan menggunakan uji $\mathrm{F}$ pada taraf $\alpha=5 \%$ dan perbedaan antar perlakuan diuji dengan Uji Jarak Berganda Duncan (DMRT). Hasil penelitian menunjukkan bahwa genotipe kedelai memiliki mekanisme berbeda untuk mendapatkan $\mathrm{P}$ dari dalam tanah mineral masam kahat P. Genotipe lama (Slamet) memiliki mekanisme peningkatan aktivitas fosfatase alkalin dan serapan $\mathrm{P}$ spesifik (P-Al, P-Fe dan P tersekap). Genotipe 19BE memiliki mekanisme translokasi karbon ke akar atau penurunan NPA dan serapan $\mathrm{P}$ spesifik yang lebih terbatas ( $\mathrm{P}-\mathrm{Al}$ dan $\mathrm{P}-\mathrm{Fe}$ ) sedangkan genotipe 25EC menurunkan NPA dan menyerap P-Fe saja. Pemupukan dosis tinggi (400 mg kg-1) meningkatkan produksi biomassa, jumlah bintil akar efektif, serapan hara $\mathrm{N}$ dan $\mathrm{P}$, namun menurunkan aktivitas enzim fosfatase alkalin di rhizosfir kedelai umur 35 HST. Pemupukan P dosis tinggi menimbulkan biopriming sehingga menurunkan kadar $\mathrm{P}$ spesifik dalam tanah yang ditumbuhi oleh genotipe 19BE dan 25EC.
\end{abstract}

Kata Kunci : mekanisme adaptasi, genotipe kedelai, tanah masam, kekahatan fosfor

\section{ABSTRACT}

A research was conducted with aims (1) to identify adaptation mechanisms of new soybean genotypes in utilizing limited $P$ from acid mineral soil: through carbon translocation to root and through absorption of specific $P$, and (2) to describe the respond of soybean genotype to $P$ fertilization. Treatments, including soybean genotypes (Slamet, 19BE, and 25EC) and $P$

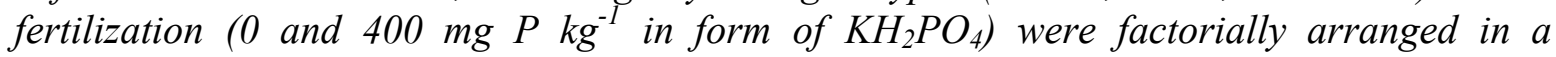
Completely Randomized Design with four replications. Soybean was planted in a green house using double pot system. The upper pot was filled with a mixture of sterile soil and volcano sand, and lower pot with non sterilized soil. The evaluation was performed at the end vegetative growth phase (R1). Evaluated variables were dry weight of shoot, root, and plant total, alkaline phosphatase activity, number of nodules, $N$ and $P$ absorption, quality specific $P$ 
index. Data variation was analyzed by using $F$-test with degree of fredoom $\alpha=5 \%$ and differences among treatments were separated by using Duncan Multiple Range Test (DMRT). The results showed that soybean genotype had different mechanism in using limited $P$ from acid mineral soil. Old genotype (Slamet) had mechanism through increasing alkaline phosphatase and absorption of specific P (P-Al, P-Fe dan P occluded). Genotype 19BE had mechanism through translocation of carbon to root or decreasing of shoot-root ratio; specific $P$ absortion (P-Al dan P-Fe) was limited. Genotype 25EC had only decreased shoot-root ratio and $P$-Fe absortion mechanism. Fertilization with high $P\left(400 \mathrm{mg} \mathrm{kg}^{-1}\right)$ increased biomass production, number of root nodules, absortion $N$ and $P$ nutrients; however it decreased absorption alkaline-phosphatase activity at soybean rhizosphere at 35 day after planting. Fertilizing high dosage $P$ created biopriming by decreasing the qualtity specific $P$ on soil under 19BE and 25EC genotypes.

Keywords : adaptation mechanism, soybean genotypes, acid soil, P acquisition

\section{PENDAHULUAN}

Kebutuhan nasional kedelai dewasa ini mencapai 2,2 juta ton tahun ${ }^{-1}$. Produksi kedelai dalam negeri baru mampu memenuhi kebutuhan sebesar $35-40 \%$, sehingga kekurangannya dipenuhi dari impor (Balitbangtan, 2008). Peningkatan produksi kedelai dicapai melalui empat strategi. Salah satunya dengan perluasan areal tanam yang diarahkan pada lahan kering masam (Balitbangtan, 2008).

Pengelolaan tanah-tanah mineral masam untuk kepentingan pertanian menghadapi berbagai kendala diantaranya $\mathrm{pH}$ yang rendah, kekurangan $\mathrm{P}$ pada tanah masam dapat disebabkan oleh kandungan $\mathrm{P}$ dari bahan induk tanah yang memang sudah rendah atau kandungan $\mathrm{P}$ sebenarnya tinggi tapi tidak dapat diserap oleh tanaman karena dijerap oleh koloid $\mathrm{Al}$ dan $\mathrm{Fe}$ (Prasetyo dan Suriadikarta, 2006).
Hanya $15 \%$ dari pupuk $\mathrm{P}$ yang diberikan ke dalam tanah yang dapat diserap tanaman dan sisanya terakumulasi sebagi residu (Barchia, 2009). Hal tersebut menyebabkan terjadinya defisiensi $\mathrm{P}$ pada pertumbuhan tanaman, sehingga perlu diberikan dalam takaran yang cukup. Oleh karena itu, salah satu upaya yang dilakukan oleh pemulia tanaman ialah dengan merakit varietas dengan keunggulan efisien dalam menyerap hara $\mathrm{P}$, pertumbuhan kokoh, tinggi sedang, jumlah polong banyak, dan umur genjah. Galur-galur tersebut yaitu 11AB, 13ED, 14DD, 19BE, dan 25EC yang merupakan hasil persilangan Malabar dan Kipas Putih (Suryati et al. (1999).

Genotipe tanaman yang adaptif umumnya mengembangkan strategi adaptasi tertentu untuk mendapatkan unsur hara tertentu dari dalam tanah. Strategi adaptasi tanaman dengan demikian dapat digunakan untuk 
mengidentifikasi genotipe yang efesien menyerap bentuk-bentuk $\mathrm{P}$ dari dalam tanah (Wissuwa, 2005). Pemahaman mengenai strategi adaptasi tanaman kedelai menghadapi kekahatan $\mathrm{P}$ semestinya dijadikan acuan budidaya kedelai di tanah masam bermasalah kahat $\mathrm{P}$ sebelum sebuah genotipe tanaman dibudidayakan di lapangan.

\section{METODE PENELITIAN}

Penelitian ini dilaksanakan di rumah kaca Fakultas Pertanian Universitas Bengkulu, Laboratorium Biologi Tanah Fakultas Pertanian Universitas Bengkulu, dan Balai Penelitian Tanah Bogor. Penelitian dilaksanakan bulan Juli hingga Desember 2009. Contoh tanah diambil dari Kelurahan Kandang Limun Kecamatan Muara Bangkahulu Kota Bengkulu, Kecamatan Pondok Kelapa Kabupaten Bengkulu Tengah, Kecamatan Sukaraja Kabupaten Seluma, dan Desa Tangsi Baru Kecamatan Kabawetan Kabupaten Kepahiang.

Contoh tanah yang memiliki kapasitas retensi $\mathrm{P}$ tertinggi dari keempat sampel lokasi tersebut digunakan sebagai media dalam penelitian ini. Selanjutnya tanah yang terpilih dilakukan penetapan karakterisasi fisikokimia tanah yang meliputi tekstur tanah, kadar $\mathrm{N}, \mathrm{P}, \mathrm{K}$ dan kation tertukar, dan kadar C (Prasetyo et al., 2005).

Penanaman kedelai dilaksanakan menggunakan sistem pot ganda (Gambar 1) terbuat dari dua buah pipa pralon dengan diameter $10.16 \mathrm{~cm}$ yang terdiri atas dua bagian yaitu (1) bagian atas panjangnya \pm $10 \mathrm{~cm}$ yang bagian bawahnya ditutup dengan mesh nilon berukuran $35 \mu \mathrm{m}$, dengan harapan tidak dapat dilalui akar dan (2) bagian bawah panjangnya $5 \mathrm{~cm}$.

Kedalam pipa pralon bagian atas diisi media tumbuh berupa campuran tanah steril (20\%) dan pasir gunung (80\%). Pupuk dasar yang diberikan berupa $140 \mathrm{mg} \mathrm{kg}^{-1} \mathrm{~K}_{2} \mathrm{SO}_{4}, 150$ $\mathrm{mg} \mathrm{kg}^{-1} \quad \mathrm{CaCl}_{2} \cdot 2 \mathrm{H}_{2} \mathrm{O}, \quad 20 \mathrm{mg} \quad \mathrm{kg}^{-1}$ $\mathrm{MgSO}_{4} \cdot 7 \mathrm{H}_{2} \mathrm{O}, 15 \mathrm{mg} \mathrm{kg}^{-1} \mathrm{MnSO}_{4} \cdot \mathrm{H}_{2} \mathrm{O}, 9$ $\mathrm{mg} \quad \mathrm{kg}^{-1} \quad \mathrm{ZnSO}_{4} \cdot 7 \mathrm{H}_{2} \mathrm{O}, \quad 2 \mathrm{mg} \quad \mathrm{kg}^{-1}$ $\mathrm{CuSO}_{4} .5 \mathrm{H}_{2} \mathrm{O}, 0.7 \mathrm{mg} \mathrm{kg}^{-1} \mathrm{H}_{3} \mathrm{BO}_{3}, 5.5 \mathrm{mg}$ $\mathrm{kg}^{-1}$ FeEDTA, dan $0.2 \mathrm{mg} \quad \mathrm{kg}^{-1}$ $\mathrm{Na}_{2} \mathrm{MoO}_{4} \cdot 2 \mathrm{H}_{2} \mathrm{O}$. Nitrogen diberikan setiap minggu dalam bentuk $\mathrm{Ca}\left(\mathrm{NO}_{3}\right)_{2}$ dengan dosis $32 \mathrm{mg} \mathrm{N} \mathrm{kg}^{-1}$ setelah tanam. Unsur hara fosfor diberikan dalam bentuk $\mathrm{KH}_{2} \mathrm{PO}_{4}$ sesuai dengan takaran yang diuji untuk menciptakan kondisi tanpa pemupukan $\mathrm{P} /$ kahat $\mathrm{P}\left(0 \mathrm{mg} \mathrm{P} \mathrm{kg}^{-1}\right)$ dan pemupukan $\mathrm{P}$ dosis tinggi (400 $\mathrm{mg} \mathrm{P} \mathrm{kg}^{-1}$ ).

Setelah pemupukan, media tumbuh ditanami dengan tiga benih kedelai. Pada 
umur 15 hari setelah tanam (HST) bobotnya konstan. Dilakukan pengamatan dilakukan penjarangan dengan menyisakan terhadap jumlah bintil akar efektif dan satu tanaman terbaik. Pada saat terjadinya aktivitas fosfatase alkalin. Serapan N dan P, gejala kekahatan $\mathrm{P}$ bagian atas tersebut kemudian diletakkan pada permukaan Kadar hara $\mathrm{N}$ tanaman dan fraksi $\mathrm{P}$ spesifik tanah, Kadar N , kadar P. Data dinyatakan bagian bawah dari sistem yaitu pipa pralon setinggi $\pm 5 \mathrm{~cm}$ berisi contoh tanah tidak steril yang memiliki kapasitas retensi $\mathrm{P}$ tertinggi. Percobaan diakhiri ketika tanaman kedelai telah mencapai fase vegetatif yaitu pada umur 35 HST.

Peubah yang diamati ialah Bobot kering bagian atas, akar, dan total tanaman diukur berdasarkan bobot kering oven $80^{\circ} \mathrm{C}$ sampai dalam Indeks P Spesifik yaitu persentase kadar P spesifik pada tanah yang mendapat perlakuan terhadap kadar $\mathrm{P}$ spesifik perlakuan kontrol (Bertham et al., 2009). Data yang diperoleh diuji secara statistika dengan menggunakan uji $\mathrm{F}$ pada taraf $\alpha=$ $5 \%$ dan perbedaan antar perlakuan diuji dengan Uji Jarak Berganda Duncan (DMRT).

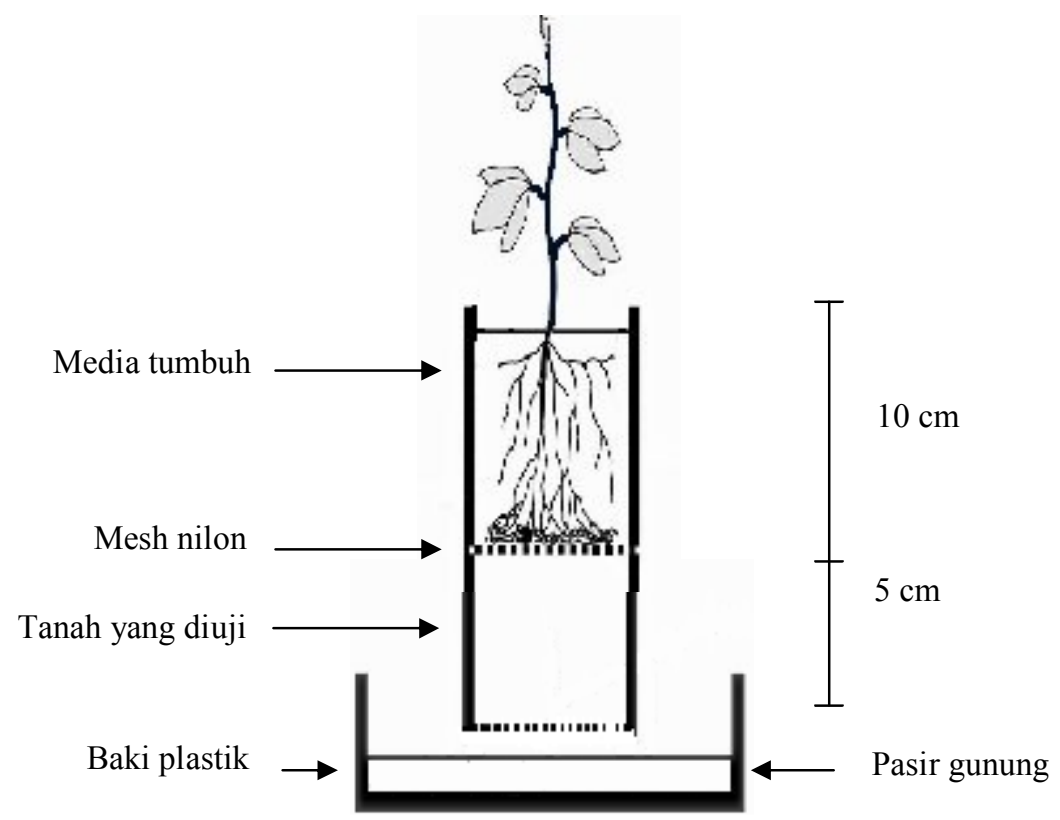




\section{HASIL DAN PEMBAHASAN}

Berdasarkan hasil analisa, dari keempat lokasi, Desa Tangsi Baru memiliki retensi $\mathrm{P}$ yang paling tinggi (67,64\%) bila dibandingkan dengan daerah Kandang Limun (19,38\%), Pondok Kelapa (26,65\%), dan Sukaraja (26,36\%). Dengan demikian dapat disimpulkan bahwa tanah dari lokasi Desa Tangsi Baru digunakan untuk lokasi sampel penelitian (Tabel 1).

\section{Translokasi Karbon}

Genotipe Slamet pada kondisi kahat $\mathrm{P}$ memiliki bobot kering akar yang jauh lebih rendah tetapi bobot kering pucuknya sama dengan genotipe 19BE dan 25EC. Genotipe 19BE dan 25EC pada kondisi kahat $\mathrm{P}$ memiliki nilai NPA yang sama besarnya namun nyata lebih kecil dibandingkan dengan Slamet. Nisbah pucuk akar varietas Slamet pada kondisi kahat $\mathrm{P}$ jauh lebih tinggi dibandingkan dengan 19BE dan 15EC. Sebaliknya, pada kondisi kecukupan $\mathrm{P}$ varietas Slamet menurunkan NPA sebesar $13 \%$ sedangan genotipe $19 \mathrm{BE}$ dan $25 \mathrm{EC}$ justru meningkatkan NPA masing-masing sebesar $88 \%$ dan $91 \%$ (Tabel 2).

Tabel .1. Karakteristik Fisikokimia Tanah dari Empat Lokasi

\begin{tabular}{|c|c|c|c|c|c|c|c|c|}
\hline \multirow{2}{*}{ Karakteristik } & \multicolumn{2}{|c|}{ Kandang Limun } & \multicolumn{2}{|l|}{ Tangsi Baru } & \multicolumn{2}{|c|}{ Pondok Kelapa } & \multicolumn{2}{|l|}{ Sukaraja } \\
\hline & Nilai & $*$ & Nilai & $*$ & Nilai & $*$ & Nilai & $*$ \\
\hline $\mathrm{pH} \mathrm{H} \mathrm{H}_{2} \mathrm{O}$ & 5,50 & $\mathrm{M}$ & 5,70 & AM & 5,20 & $\mathrm{M}$ & 5,50 & $\mathrm{M}$ \\
\hline $\mathrm{KCl} 1 \mathrm{~N}$ & 4,40 & & 4,70 & & 4,30 & & 4,50 & \\
\hline C organik (\%) & 2,12 & $\mathrm{~S}$ & 4,14 & $\mathrm{~T}$ & 3,53 & $\mathrm{~T}$ & 2,63 & $\mathrm{~S}$ \\
\hline $\mathrm{N}$ total $(\%)$ & 0,18 & $\mathrm{R}$ & 0,29 & $\mathrm{~S}$ & 0,27 & $\mathrm{~S}$ & 0,19 & $\mathrm{R}$ \\
\hline Nisbah C/N & 11,80 & $\mathrm{~S}$ & 14,30 & S & 13,10 & S & 13,80 & $\mathrm{~S}$ \\
\hline P tersedia (ppm) & 5,30 & $\mathrm{R}$ & 8,70 & $\mathrm{R}$ & 9,70 & $\mathrm{R}$ & 5,40 & $\mathrm{R}$ \\
\hline Retensi P (\%) & 19,38 & & 67,64 & & 26,65 & & 26,36 & \\
\hline Kapasitas jerapan $\mathrm{P}\left(\mathrm{mg} \mathrm{kg}^{-1}\right)$ & 1111,00 & & 3333,00 & & 1111,00 & & 1250,00 & \\
\hline $\begin{array}{l}\text { Kapasitas tukar kation }\left[\mathrm{cmol}(+) \mathrm{kg}^{-}\right. \\
\left.{ }^{1}\right]\end{array}$ & 17,85 & $\mathrm{~S}$ & 22,85 & $\mathrm{~S}$ & 17,85 & $\mathrm{~S}$ & 12,85 & $\mathrm{R}$ \\
\hline Kejenuhan basa (\%) & 43,50 & $\mathrm{~S}$ & 44,70 & $\mathrm{~S}$ & 46,60 & S & 65,20 & $\mathrm{~T}$ \\
\hline Kejenuhan $\mathrm{Al}(\%)$ & 1,18 & SR & - & SR & 1,06 & SR & 1,32 & SR \\
\hline Sebaran butir Pasir (\%) & 33,00 & & 43,10 & & 23,10 & & 33,50 & \\
\hline Debu $(\%)$ & 13,00 & & 25,30 & & 21,10 & & 19,20 & \\
\hline Lempung $(\%)$ & 54,00 & & 31,60 & & 45,80 & & 47,30 & \\
\hline Tekstur & Lempung & & $\begin{array}{l}\text { Geluh } \\
\text { berlempung }\end{array}$ & & Lempung & & Lempung & \\
\hline
\end{tabular}


Varietas Slamet memiliki respon tertinggi dalam hal peningkatan bobot kering akar $(247 \%)$ sedangkan genotipe 25EC responnya tertinggi dalam hal peningkatan bobot kering pucuk (302\%) dan bobot kering total (227\%). Respon dalam hal bobot kering total oleh genotipe 25EC semata-mata karena responnya yang lebih tinggi dalam hal peningkatan bobot kering pucuk.

Membaiknya fungsi akar berdampak positif terhadap bagian atas tanaman yang ditunjukkan dengan adanya korelasi positif antara bobot kering akar dengan bobot kering bagian atas tanaman $(r=0,92)$ (Gambar 1)

Tabel .2. Pengaruh genotipe dan pemupukan $\mathbf{P}$ terhadap berat kering dan nisbah pucuk akar tanaman kedelai umur 35 HST

\begin{tabular}{|c|c|c|c|c|c|}
\hline \multirow{2}{*}{$\begin{array}{l}\text { Genotipe } \\
\text { kedelai }\end{array}$} & \multirow{2}{*}{$\begin{array}{l}\text { Pupuk P } \\
\left(\mathrm{mg} \mathrm{kg}^{-1}\right)\end{array}$} & \multicolumn{3}{|c|}{ Bobot kering (g) } & \multirow{2}{*}{$\begin{array}{c}\text { Nisbah pucuk } \\
\text { akar }\end{array}$} \\
\hline & & Akar & Pucuk & Total & \\
\hline \multirow{2}{*}{ Slamet } & 0 & $0,58 \mathrm{c}$ & $2,61 \mathrm{c}$ & 3,19 & $4,50 \mathrm{a}$ \\
\hline & 400 & 2,01 a (247) & 7,70 b (195) & $9,71(204)$ & $3,91 \mathrm{ab}(-13)$ \\
\hline \multirow{2}{*}{$19 \mathrm{BE}$} & 0 & $1,33 \mathrm{~b}$ & $2,56 \mathrm{c}$ & 3,89 & $1,99 \mathrm{c}$ \\
\hline & 400 & 2,41 a $(81)$ & 9,01 a (252) & 11,42 (194) & 3,74 b (88) \\
\hline \multirow{2}{*}{$25 \mathrm{EC}$} & 0 & $1,18 \mathrm{~b}$ & $2,03 \mathrm{c}$ & 3,21 & $1,84 \mathrm{c}$ \\
\hline & 400 & 2,33 a (97) & 8,17 b (302) & $10,50(227)$ & $3,52 \mathrm{~b}(91)$ \\
\hline Genotipe (G) & & $24,80 * *$ & $5,63 * *$ & $17,29 * *$ & $28,62 * *$ \\
\hline Pupuk (P) & & $217,80 * *$ & $923,08 * *$ & $1693,56 * *$ & $28,10 * *$ \\
\hline $\mathrm{G} \times \mathrm{P}$ & & $7,80 * *$ & $5,33 * *$ & $0,60^{\mathrm{ns}}$ & $18,32 * *$ \\
\hline KK (\%) & & 0,9 & 0,6 & 1 & 14 \\
\hline Keterangan & \multicolumn{5}{|c|}{$\begin{array}{l}\text { ** = berbeda sangat nyata, } \mathrm{ns}=\text { berbeda tidak nyata pada taraf } 5 \% \text {. Rerata diikuti } \\
\text { huruf sama menunjukkan berbeda tidak nyata berdasarkan Uji Jarak Berganda } \\
\text { Duncan (DMRT) pada taraf nyata } 5 \% \text {. Angka dalam tanda kurung merupakan } \\
\text { persentase peningkatan. }\end{array}$} \\
\hline
\end{tabular}

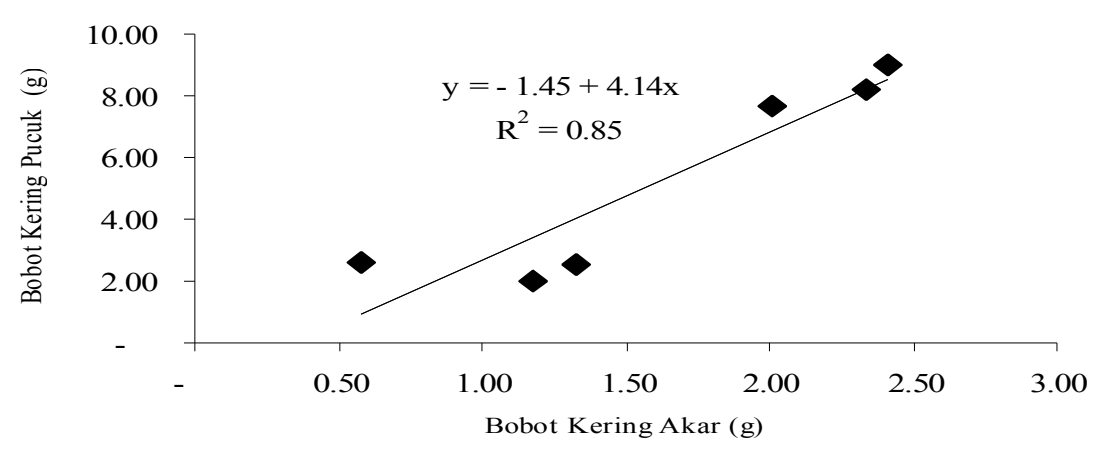

Gambar.1. Korelasi antara bobot kering akar dan bobot kering pucuk tanaman kedelai umur 35 HST 


\section{Aktivitas Biologi dan Serapan Hara N dan P}

Tabel.3. Pengaruh genotipe dan pemupukan $P$ terhadap aktivitas biologi di rhizosfir dan serapan hara oleh tanaman kedelai umur 35 HST

\begin{tabular}{|c|c|c|c|c|c|}
\hline \multirow{2}{*}{$\begin{array}{l}\text { Genotipe } \\
\text { kedelai }\end{array}$} & \multirow{2}{*}{$\begin{array}{l}\text { Pupuk P } \\
\left(\mathrm{mg} \mathrm{kg}^{-1}\right)\end{array}$} & \multicolumn{2}{|c|}{ Aktivitas biologi } & \multicolumn{2}{|c|}{ Serapan hara } \\
\hline & & $\begin{array}{c}\text { Aktivitas } \\
\text { fosfatase alkalin }\end{array}$ & $\begin{array}{l}\sum \text { bintil akar } \\
\text { efektif (buah) }\end{array}$ & P (mg) & $\mathrm{N}(\mathrm{mg})$ \\
\hline \multirow{2}{*}{ Slamet } & 0 & $6,01 \mathrm{a}$ & $3 \mathrm{e}$ & $6,88 \mathrm{~d}$ & $57,38 \mathrm{c}$ \\
\hline & 400 & 0,02 e $(-100)$ & 104 c (4040) & 33,46 с (386) & $170,59 \mathrm{~b}(197)$ \\
\hline \multirow{2}{*}{ 19BE } & 0 & $2,29 \mathrm{~b}$ & $12 \mathrm{~d}$ & $6,99 \mathrm{~d}$ & $68,40 \mathrm{c}$ \\
\hline & 400 & $0,78 \mathrm{~d}(-66)$ & 242 a (2004) & 51,45 a (636) & 291,55 a (326) \\
\hline \multirow{2}{*}{$25 \mathrm{EC}$} & 0 & $0,36 \mathrm{~d}$ & $2 \mathrm{e}$ & $7,03 \mathrm{~d}$ & $56,67 \mathrm{c}$ \\
\hline & 400 & 0,04 e $(-89)$ & $147 \mathrm{~b}(9700)$ & 39,86 b (467) & 290,46 a (234) \\
\hline Genotipe (G) & & $598,20 * *$ & $119,32 * *$ & $22,89 * *$ & $38,23 * *$ \\
\hline Pupuk (P) & & $1543,64 * *$ & $2968,12 * *$ & $979,41 * *$ & $782,02 * *$ \\
\hline Gx P & & $676,53 * *$ & $14,26 * *$ & $22,42 *$ & $32,16 * *$ \\
\hline KK $(\%)$ & & 7 & 4 & 8 & 8 \\
\hline
\end{tabular}

Keterangan : $\quad * *=$ berbeda sangat nyata, $*=$ berbeda nyata pada taraf $5 \%$. Rerata diikuti huruf sama menunjukkan berbeda tidak nyata berdasarkan Uji Jarak Berganda Duncan (DMRT) pada taraf nyata 5\%. Angka dalam tanda kurung merupakan persentase peningkatan.

Aktivitas fosfatase alkalin tertinggi terdapat pada rhizosfir kedelai genotipe Slamet sedangkan yang terendah pada rhizosfir genotipe 25EC. Aktivitas fosfatase alkalin pada ketiga genotipe kedelai menjadi menurun jika dipupuk $\mathrm{P}$ dengan dosis tinggi, penurunannya berkisar 66$100 \%$ bergantung kepada genotipe kedelainya.

Biomassa akar terendah (Tabel .2) namun diikuti dengan aktivitas fosfatase alkalin tertinggi (Tabel .3) menunjukkan sebagian karbon yang ditranslokasikan ke akar genotipe Slamet dilepaskan dalam bentuk eksudat akar agar populasi jasad renik di rhizosfir meningkat. Peningkatan populasi dan aktivitas jasad renik rhizosfir tersebut menyebabkan meningkatnya aktivitas fosfatase alkalin di rhizosfir.

Pada kondisi kahat $\mathrm{P}$ hanya genotipe 19BE yang mampu membentuk bintil akar efektif dalam jumlah yang lebih banyak. Peningkatan kadar $\mathrm{P}$ tanah melalui pemupukan $\mathrm{P}$ dosis tinggi secara drastis meningkatkan jumlah bintil akar efektif. Jumlah bintil akar terbanyak dihasilkan oleh genotipe 19BE diikuti oleh 25EC dan Slamet, namun demikian peningkatan jumlah bintil akar terbesar justru dihasilkan oleh 25EC (9700\%) diikuti oleh Slamet (4040\%) dan 19BE (2004\%) yang terendah. Peningkatan jumlah bintil erat kaitannya dengan peningkatan $\mathrm{P}$ di dalam tanah terutama sumber energi sel (ATP) yang 
diperlukan untuk metabolisme sel seperti akar (Hevlin et al., 1999). Hipothesis demikian terjawab dengan nilai korelasi positif $(r=0,98)$ (Gambar 2).

Peningkatan jumlah dan aktivitas bintil akar akan meningkatkan perolehan $\mathrm{N}_{2}$ dari udara melalui proses sematan hayati oleh bakteri Rhizobium. Semakin besar bintil atau semakin banyaknya jumlah bintil akar yang terbentuk maka akan semakin besar nitrogen yang ditambat oleh Rhizobium tersebut. Jumlah bintil akar efektif juga berkorelasi positif $(\mathrm{r}=0,95)$ (Gambar 3) dengan serapan $\mathrm{N}$ oleh tanaman kedelai umur 35 HST sebagaimana telah dilaporkan sebelumnya (Rotaru dan Sinclair, 2009).

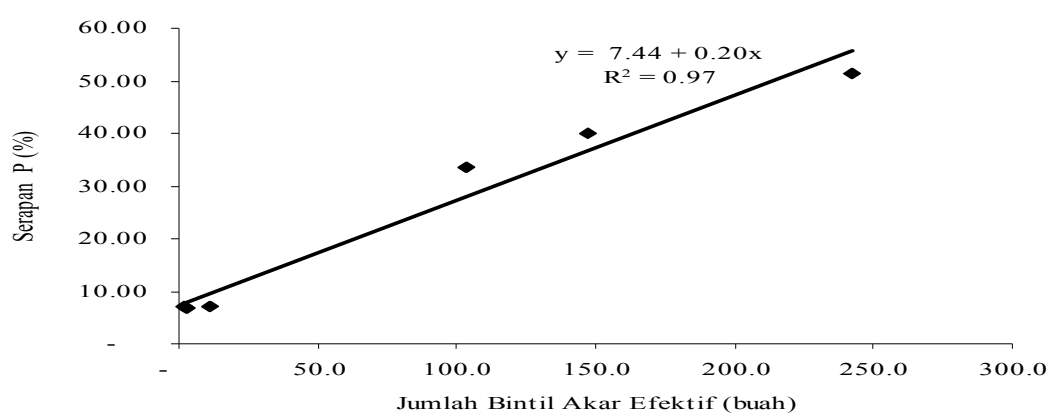

Gambar .2. Korelasi antara jumlah bintil akar efektif dan serapan $P$ tanaman kedelai umur 35 HST

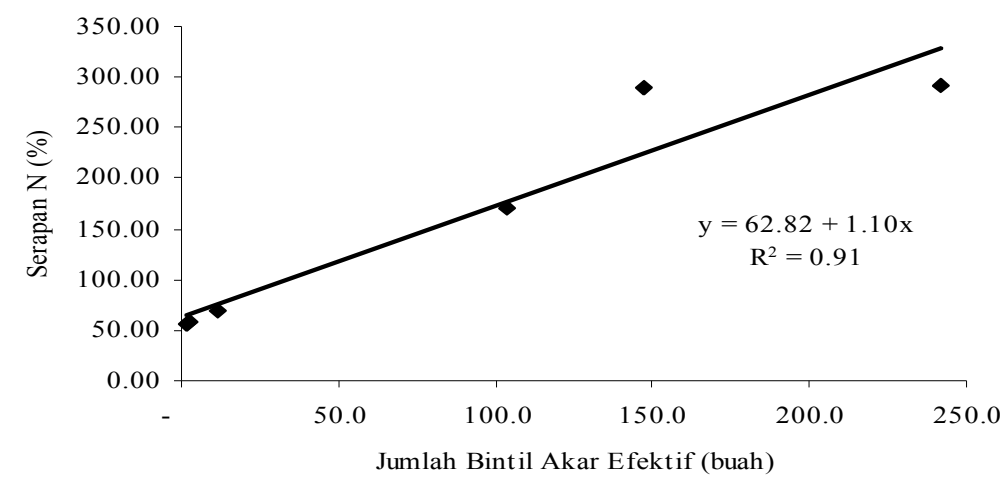

Gambar 3. Korelasi antara jumlah bintil akar efektif dan serapan $\mathbf{N}$ tanaman kedelai umur 35 HST 
Pemupukan $\mathrm{P}$ dosis tinggi menghasilkan serapan $\mathrm{P}$ tertinggi pada genotipe 19BE diikuti oleh 25EC dan Slamet, namun demikian genotipe 19BE dan 25EC memiliki serapan $\mathrm{N}$ yang sama besarnya dan berbeda nyata dengan varietas Slamet. Hanya genotipe 19BE yang memiliki peningkatan serapan $\mathrm{P}(636 \%)$ dan $\mathrm{N}$ (326\%) tertinggi jika dibandingkan dengan 25EC dan Slamet..

\section{Pelepasan P Spesifik Tanah}

Genotipe kedelai, pemupukan $\mathrm{P}$, dan interaksi keduanya berpengaruh nyata terhadap Indeks Kadar P Spesifik (P-Al, P$\mathrm{Fe}, \mathrm{P}$ tersekap dan $\mathrm{P}$ residual) (Tabel.4).
Varietas Slamet banyak memanfaatkan P$\mathrm{Al}, \mathrm{P}-\mathrm{Fe}$, dan $\mathrm{P}$ tersekap, genotipe 19BE memanfaatkan P-Al dan P-Fe, sedangkan genotipe 25EC hanya memanfaatkan P-Fe. Penanaman kedelai genotipe Slamet berdampak meningkatkan kadar P residual, genotipe 19BE meningkatkan kadar $\mathrm{P}$ residual dan $\mathrm{P}$ tersekap, sedangkan genotipe 25EC meningkatkan kadar P-Al, $\mathrm{P}$ tersekap, dan $\mathrm{P}$ residual pada kondisi kahat P. Pada kondisi kecukupan $\mathrm{P}$ ternyata setiap genotipe juga berbeda perilakunya. Varietas Slamet banyak memanfaatkan PAl, genotipe 19BE memanfaatkan semua bentuk $\mathrm{P}$ spesifik, sedangkan genotipe 25EC memanfaatkan P-Al, P tersekap dan $\mathrm{P}$ residual.

Tabel.4. Pengaruh genotipe kedelai dan pemupukan $P$ terhadap Indeks Kadar P Spesifik tanah

\begin{tabular}{lcrrrr}
\hline \multirow{2}{*}{ Genotipe kedelai } & $\begin{array}{c}\text { Pupuk P }(\mathrm{mg} \\
\left.\mathrm{kg}^{-1}\right)\end{array}$ & \multicolumn{5}{c}{ Indeks Kadar P Spesifik (\%) } \\
\cline { 2 - 6 } & 0 & $76,79 \mathrm{c}$ & $97,71 \mathrm{~b}$ & $85,76 \mathrm{c}$ & $422,67 \mathrm{a}$ \\
\multirow{2}{*}{ Slamet } & 0 & $89,47 \mathrm{~b}$ & $102,00 \mathrm{ab}$ & $108,03 \mathrm{~b}$ & $122,88 \mathrm{c}$ \\
& 40 & $92,22 \mathrm{~b}$ & $96,58 \mathrm{~b}$ & $129,48 \mathrm{a}$ & $388,00 \mathrm{ab}$ \\
19BE & 0 & $63,93 \mathrm{~d}$ & $62,75 \mathrm{~d}$ & $84,75 \mathrm{c}$ & $61,44 \mathrm{~d}$ \\
& 400 & $100,25 \mathrm{a}$ & $88,31 \mathrm{c}$ & $103,52 \mathrm{~b}$ & $353,33 \mathrm{~b}$ \\
25EC & 0 & $81,12 \mathrm{c}$ & $105,27 \mathrm{a}$ & $93,25 \mathrm{c}$ & $43,79 \mathrm{e}$ \\
\hline Genotipe (G) & 400 & $27,83 * *$ & $70,26 * *$ & $6,97 *$ & $58,48 * *$ \\
Pupuk (P) & & $69,53 * *$ & $7,84 *$ & $22,79 * *$ & $1709,23 * *$ \\
G x P & & $79,89 * *$ & $103,65 * *$ & $75,32 * *$ & $21,33 * *$ \\
\hline KK (\%) & 3 & 3 & 2 & 2 \\
\hline
\end{tabular}

Keterangan : $\quad * *=$ berbeda sangat nyata, $*=$ berbeda nyata pada taraf $5 \%$. Rerata diikuti huruf sama menunjukkan berbeda tidak nyata berdasarkan Uji Jarak Berganda Duncan (DMRT) pada taraf nyata 5\%. 
Genotipe 19BE dan 25EC masing-masing mentranslokasikan $67 \%$ dan $64 \%$ dari seluruh biomassa yang terbentuk menjadi akar sedangkan varietas Slamet hanya 13\% untuk mendapatkan $\mathrm{P}$ dari tanah mineral masam kahat P (Tabel.2). Sebagian karbon digunakan untuk pembentukan biomassa akar dan sebagian lainnya dilepaskan sebagai eksudat akar. Eksudat yang dilepaskan dapat berbentuk asam-asam organik yang digunakan untuk melarutkan P-anorganik (P-Al dan P-Fe), meningkatkan aktivitas enzim fosfatase alkalin untuk memineralisasikan $\mathrm{P}$ organik dari tanah mineral masam, atau meningkatkan populasi dan aktivitas jasad renik yang terlibat dalam proses biogeokimia P (Bertham et al., 2009). Pemupukan $\mathrm{P}$ dosis tinggi ternyata juga dapat meningkatkan atau menurunkan kadar P spesifik di rhizosfir bergantung kepada genotipe kedelainya (Tabel 3). Pemupukan $\mathrm{P}$ dosis tinggi pada genotipe Slamet menyebabkan peningkatan kadar PFe, P-tersekap, dan P-residual, sedangkan pada genotipe 25EC hanya meningkatkan kadar P-Fe. Sebaliknya pemupukan P dosis tinggi menurunkan kadar semua jenis $P$ spesifik. Pemupukan $\mathrm{P}$ dosis tinggi secara drastis meningkatkan produksi biomassa tanaman (Tabel 2) dan jumlah bintil akar efektif(Tabel 3).

\section{SIMPULAN}

Genotipe kedelai memiliki mekanisme berbeda untuk mendapatkan $\mathrm{P}$ dari dalam tanah mineral masam kahat P. Genotipe lama (Slamet) memiliki mekanisme peningkatan aktivitas fosfatase alkalin dan serapan $\mathrm{P}$ spesifik (P-Al, P-Fe dan $\mathrm{P}$ tersekap). Genotipe 19BE memiliki mekanisme translokasi karbon ke akar atau penurunan NPA dan serapan $\mathrm{P}$ spesifik yang lebih terbatas (P-Al dan P-Fe) sedangkan genotipe 25EC menurunkan NPA dan menyerap P-Fe saja.

Secara umum pemupukan $\mathrm{P}$ dosis tinggi pada genotipe 19BE menghasilkan produksi biomassa, jumlah bintil akar efektif, serapan hara $\mathrm{N}$ dan $\mathrm{P}$ lebih tinggi dibandingkan genotipe 25EC dan Slamet. Peningkatan bobot kering pucuk genotipe baru (19BE dan 25EC) lebih tinggi (252$302 \%$ ) jika dibandingkan dengan genotipe lama Slamet (195\%) sekalipun peningkatan bobot kering totalnya kurang lebih sama (194-227\%). Sekalipun jumlah bintil akar pada genotipe 19BE dan 25EC lebih banyak (147-242 buah) dibandingkan Slamet (104 buah) namun peningkatan jumlah bintil akar tertinggi mengikuti 
urutan 25 EC $(9700 \%)>$ Slamet $(4040 \%)>$ 19BE (2004\%). Genotipe 19BE dan 25EC lebih efisien menyerap $\mathrm{P}$ dan $\mathrm{N}$ pada kondisi kecukupan $\mathrm{P}$ sehingga menghasilkan peningkatan serapan P (467636\%) dan $\mathrm{N}$ (234-326\%) dibandingkan dengan Slamet (386\% dan 197\%). Pemupukan $\mathrm{P}$ dosis tinggi menimbulkan biopriming sehingga menurunkan kadar $\mathrm{P}$ tersekap dan $\mathrm{P}$ residual dalam tanah yang ditumbuhi oleh genotipe 19BE dan 25EC.

\section{DAFTAR PUSTAKA}

Badan Litbang Pertanian. 2008. Ketersediaan teknologi dalam mendukung peningkatan produksi kedelai menuju swasembada. Siaran Pers Badan Penelitian dan Pengembangan Pertanian tanggal 12 Februari 2008.

Barchia, M.F. 2009. Agroekosistem tanah mineral masam. Gadjah Mada University Press. Yogyakarta.

Bertham, Y.H., A.D. Nusantara, dan H. Pujiwati. 2009. Peningkatan produktivitas genotipe baru kedelai berbasis mekanisme adaptasi mendapatkan hara fosfor dari tanah Ultisol. Laporan Penelitian Hibah Kompetitif Sesuai Prioritas Nasional. Lembaga Penelitian
UNIB-DP2M Ditjen Dikti Kementrian Pendidikan Nasional. Havlin, J.L., J.D. Beaton, S.L. Tisdale, and W.L. Nelson. 1999. Soil fertility and fertilizers. An introduction to nutrient management. $6^{\text {th }}$ Ed. Prentice Hall. New Jersey.

Prasetyo, B.H. dan D.A. Suriadikarta. 2006. Karakteristik, potensi, dan teknologi pengolahan tanah ultisol untuk pengembangan pertanian lahan kering di Indonesia. J. Litbang Pertanian 25 (2) : 39-46.

Prasetyo, B.H., D. Santoso, dan L.R. Widowati. 2005. Petunjuk teknis analisis kimia tanah, tanaman, air, dan pupuk. Balai Penelitian Tanah Bogor. Bogor.

Rotaru V., and T.R. Sinclair. 2009. Interactive influence of phosphorus and iron on nitrogen fixation by soybean. Environmental and Experimental Botany 66 : 94-99

Suryati, D., A. Munawar, Hasanudin, D.W. Genefianti, dan D. Apriyanto. 1999. Perakitan varietas kedelai (Glycine max (L.) Merril) yang efisien menyerap hara $P$ : Pewarisan sifat efesien hara $P$ (Penelitian Tahap III). Lembaga Penelitian Universitas Bengkulu. Bengkulu.

Wissuwa, M. 2005. Combining a modelling with a genetic approach in establishing associations between genetic and physiological effects in relation to phosphorus uptake. Plant and Soil 269 : 57-68. 